\title{
An Analysis Of The Tourism In Nepal Trend Of Tourist Arrivals
}

\author{
Keshav Raj Dhakal \\ Lecturer, Department of Geography Education, T. U., Nepal \\ dhakalkeshav@hotmail.com
}

\begin{abstract}
Tourism is the travel of people from one place to another; whether it is within their own country or to other countries. It is naturally a human character. Attraction is the most causative element of tourism. Various natural and cultural heritages of Nepal, its diverse topography, varied climate, its diverse flora and fauna, different shrines and temples, jungle safari and trekking attract tourists in Nepal. This study uses the data of the Nepal tourism statistics 2012 published by Ministry of Culture, Tourism and Civil Aviation. The Rana ruler isolated Nepal from external influences for a hundred and four years. During that period, Nepal was a 'forbidden land' for foreigners. Tourism in Nepal was promoted after the establishment of democracy in 1951. Tourists' influx shows a steady trend in different periods in Nepal. The average length of stay of tourist is not so long. The tourist flow in Nepal is generally confined during the spring and autumn seasons. The recent trend of tourists' arrival in Nepal seems satisfactory.
\end{abstract}

Key Words: Travelling, tourists, influx, heritage, flora and fauna, pleasure, mountaineering, pilgrimage.

\section{INTRODUCTION}

The literal meaning of tourism is the practice of touring or travelling and services for tourists. Tourism refers to the movement or journey of human beings from one place to another, whether it is within one's own country or other countries. It is related to the movement of people from one place to another in leisure time for the purpose of getting pleasure. It can also be for business, pilgrimage and other purposes. Tourism is the result of temporary movement of people to designations outside their normal places of work and residence, the activities undertaken during their stay in those destinations and the facilities created to cater to their needs (Ghimire, 2004). Tourism is the temporary short term movement of people to destinations, outside the places where they normally live and work and their activities during the stay at these destination. Tourism is the movement or travel of people from one place to another; whether it is within their own country or to other countries, for pleasure, business, pilgrimage and other purpose. The word tourism involves three basic elements: tour, tourist and to organize a business to provide the travel related services. Tourism in this sense is a service industry operated to facilitate the tour for the tourists.

Tourism is therefore considered as an important sector for development in all parts of the world. Tourism is a composite of all activities, services, and industries that delivers a travel experience, namely transportation, accommodations, eating and drinking establishments, shops, entertainment, activity facilities, and other hospitality services available for individuals or groups that are travelling away from home. Tourism has experienced continued growth and diversification to become one of the fastest growing economic sectors in the world. The evolution of tourism dates back to ancient times. Traveling, in the remote past, was mandatory because the very survival and existence of primitive men depended on it. However, the advent of civilization brought about changes in human perception and the focus of traveling shifted from one of the necessity to a desire for adventure (Ranjit, 1976). Later, the introduction and development of the modern means of transportation and communication have contributed to tourism growth by facilitating and augmenting traveling activities (Shrestha, 1978). Today, tourism industry is rapidly growing worldwide and its role is significant in the socio-economic sector of all countries. Tourism is an important source of foreign exchange earnings, provides employment opportunities and helps in economic growth of the country. It is considered as a smokeless industry in the world.

Man has been travelling throughout the ages. Travelling is human character but tourism is a new phenomenon. Before the development of transport, travel was limited to certain people and to certain places. Transport is the necessary precondition of tourism. Tourist and tourism is so much connected with transport system (Ghimire, 2004). The rapid growth of tourism in the world started only after the Second World War. The realization for the need of development in almost all countries, increasing liberalization of foreign exchange and travel restrictions, liberal policy of governments, the aspiration for international brotherhood, etc., are the main factors contributing for the rapid growth of 
tourism (Shrestha, 1978). Other factors responsible for the enormous growth of international tourism are: availability of leisure time with the people, the rapid growth of population, the advent of Jet travel, the creation of low cost means of transport and communications, low cost hotel and restaurants, retirement age and increasing life expectancy, desire to know and see the unique life styles, traditions and cultures of people of different places, rising standard of living and so on. In the developed countries, tourism agencies are encouraging the people to travel by providing schemes of incentive travel. All these developments have led to the expansion of international tourism movement during the last few decades (http:/ / www.nepjol.info )

Nepal is a multi-ethnic, multi-cultural and multireligious country inhabited by diverse ethnic communities with different languages and religions from the Himalayan to Terai regions. The season, weather, environment, accessibility etc have direct effect on the quality of attractions. Having different natural and cultural attraction Nepal becomes important destination for tourists. Different type of flora and fauna, national parks, lakes, rivers waterfalls, mountains, caves, gorge, spas, hot spring falls under the natural attraction in Nepal. The major cultural attractions of Nepal are historical sites and buildings, archeological sites, zoo and museum, different type of events, sports, trade fair exhibitions, religious place, entertainment, festival, ceremonies etc. These attractions are the most important elements for tourist arrival in Nepal. This study investigates the trend of tourist arrival, average length of stay, purpose of visit, seasonal trend of tourist arrival, and tourist arrival by major nationalities in Nepal.

\section{MATERIALS AND METHODS}

The paper is based on secondary sources of data. This study uses the data of the Nepal tourism statistics 2012 published by the Government of Nepal, Ministry of Culture, Tourism and Civil Aviation, Singh Durbar, Kathmandu in 2013 AD. The secondary data were acquired from the review of the published and unpublished materials and electronic (Internet) materials and documents of different organizations. The data are extracted and are arranged according to the necessity of the study. The data are analyzed in the five year age interval. Simple statistical tools are applied for data analysis.

\section{TOURISM BEFORE UNIFICATION OF NEPAL}

The ancient history of Nepal is made of stories and legends which are associated with Gods and Goddess. As far as the legend goes, 'Manjushree' had made the valley it for human habitation by cutting the Chovar Hill of Kathmandu Valley with his sword and thereby letting the water low out from within the valley (Bhandari 1973). Although Manjushree, a Buddhist monk is said to have come from Tibet, yet he is regarded as the first tourist ever visiting Nepal (Ghimire,2004). It has been illustrated in the chronicle that Gautam Buddha visited Nepal during the reign of Jitedasti, the seventh Kirat King, who stayed in the western part, near Swayambhu (Satyal 1988 ). The Great King of ancient India, Ashok too had visited Nepal. King Ashok visited Lumbini, the birth place of Lord Buddha, and built the Ashok Pillar there. He then came to Kathmandu valley and built similar pillars in different places (Satyal, 1988). The Lichchhavi period started in 400 A.D. and there had been enormous progress of art and culture in the country during that period. Mandeva of Lichhavi dynasty worshipped at Changu and erected a stone pillar. In Nepalese history, the Lichchhavi period is regarded very significant from the tourism viewpoint.

The marriage of Tsrong Tseng Gampo and Bhrikuti a Nepali princess, who is worshipped as green tara the daughter of King Amshuvarma, gave rise to the establishment of special relations between the two countries. As a result, it was natural for the people of these countries to travel from one country to the other. Several prominent leaders, scholars, and writers visited Nepal during this time and they have highlighted the hospitality and craftsmanship of Nepali people. Famous Chinese traveler, HuienTsang, started the journey to India in 629 A.D. According to historical evidence, after meeting King Harsabardhan of India, he returned to China via Nepal in 643 A.D. During his journey to Nepal, Huien-Tsang also visited Lumbini (Ghimire, 2004).

Malla rulers replaced the Lichhavi and developed fine art and architecture, the graceful pagodas, different festival and ceremonies. The Malla period too is of great significance in the Nepalese history. They were indebted with the responsibility of creating manmade attractions. Along with the reign of the Mallas people from the western countries began coming to Nepal with an aim to spread and publicize Christianity. Against this background, foreign tourists are found to have been attracted and visited Nepal from time immemorial. During those days, foreign tourists visiting Nepal were Chinese, Tibetan and Indians and they used to visit Nepal especially with religious and commercial motives. Nepal was a famous pilgrimage for both the Chinese and Indians. The Chinese and Tibetan religious groups used to visit Lumbini, the birth place of Lord Buddha, while the Indian religious people used to visit holy places like Pashupati Nath, Baraha Kshetra, Muktinath, Gosainkunda, 
etc. Similarly, Nepalese traders used to go to Lhasa for business purposes and the Tibetan traders too are found to have come to Nepal in connection with their business activities. Thus, religious and trading sectors are found to have contributed significantly to the development of tourism in Nepal.

Nepal and its Himalayas were unknown to the western world till the 15th century. The first recorded westerner to enter Nepal was captain Kirk Patric in 1792. Although Kirk Patrick had come to Nepal as a military official to collect facts about Nepal, his book about Nepal "An Account of the Kingdom of Nepal" helped to introduce Nepal to outsiders. After the treaty of Sugauli between the Nepal Government and the British East India Company in 1816 A.D. (Gautam, 1995), a British Resident, Dr. Wallich, was appointed in Kathmandu for developing Nepal's relationship with British India. After this there were regular visits of British nationalities in Kathmandu. After the Kot massacre, Jung Bahadur became Prime Minister and visit in Britain. Ranas closed Nepal for foreigners. The Rana autocracy isolated Nepal from external influence for a hundred and four years. During that period, Nepal was a 'forbidden land' for foreigners except for the small traders and Indian pilgrims.

\section{TOURISM AFTER UNIFICATION OF NEPAL}

After the democratic movement of 1951, tourism in Nepal was promoted. Nepal started to develop the different aspects of her social, economic and political life. 1950s can be considered as the most important period in Nepal's tourism development. Then more and more expedition teams were allowed to visit Nepal. During this period, Nepal made concrete efforts to develop tourism. It created necessary institutional infrastructure needed to promote tourism, beginning from the establishment of the Tourism Development Board in 1957 culminating to the establishment of Nepal Tourism Board in 1998. Nepal joined the membership of International Union of Official Travel Organization (IUOTO), present name, World Tourism Organization (WTO), and Pacific Area Travel Association (PATA) in 1963. With the joint effort of UNDP and ILO, Hotel Management and Tourism Training Centre was established in1972 with a view to produce trained manpower in tourism sector. This center was renamed as Nepal Academy of Tourism and Hotel Management (NATHM) in 1999.

Plans and policies were also defined for creating conducive environment for the growth of the tourism sector. In this respect, the notable efforts were the Tourism Master Plan 1972, Review of the Master
Plan 1984, and defining of Tourism Policy in 1995. For the planned development of tourism in Nepal, Nepal government joined hands with the German government to prepare the 20-year 'Tourism Master Plan, 1972'. According to the recommendation of this master plan, a separate Ministry of Tourism was established in 1977 with a view to enhance tourism properly in the country. The Tourism Ministry was named Tourism and Civil Aviation Ministry in 1991, and Culture, Tourism and Civil Aviation Ministry in 2000. In between, high level bodies like Tourism Promotion Committee and Tourism Council were formed to create the necessary paraphernalia. These activities contributed to generate important market for Nepalese tourism and the industry marched ahead in a significant manner. After the establishment of Department of Tourism in 1962, proper data about tourist arrival, purpose of their visit, length of stay, seasonal trends etc were collected.

\section{TOURIST ARRIVAL AND AVERAGE LENGTH OF STAY}

Table 1 shows total number of tourist arrival in 1962 was 6,179 and in 1965 it reached 9,388, after a decade in 1975 it reached 92,440, which was an increase by 9.8 times. Similarly, in the following decades in 1985, 1995,2005 and 2012 the total number of tourist arrivals increased 1,80,989, 3,63,395, 3,75,398 and $8,03,092$ respectively which was an increase by $19.3,38.7,40.0$ and 85.5 times respectively in every decades in comparison to the year 1965. In the year 2012 , the number of tourists reached 803,092 by recording a growth of 9.1 percent over 2011 which was the highest figure of tourist arrival in Nepal until the year 2012.

Despite the relative stagnancy and fluctuations, tourist's influx shows a steady trend in most of the occasions. The reason behind the declinations of tourist arrival by 1.5 percent in 1965 is the clash between India and Pakistan. There has been a relative stagnancy during the period 1978-79 due to the democracy movement in Nepal and oil crisis which led to decline in world tourism low. Tourist arrivals declined in the year 1989 due to trade and transit dispute between Nepal and India. Decline in tourist arrivals in 1993 may be attributed to a host of reasons viz. like the increase in Visa fees, limited air seat capacity, THAI and PIA aircraft accidents, lack of promotional activities abroad, destruction caused by floods and landslides and numerous Chakka-Jams and 'Bandha' as a part of political unrest. After 1994, the number of visitors increased since National Tourism Campaign was undertaken with a slogan "Visit Nepal Year- 1998" and "Nepal Tourism Year- 2011". 
Table 1: Tourist arrival and average length of stay, 1962-2012

\begin{tabular}{|c|c|c|c|c|c|c|c|}
\hline \multirow[t]{2}{*}{ Year } & \multicolumn{2}{|r|}{ Total } & \multicolumn{2}{|c|}{ By Air } & \multicolumn{2}{|c|}{ By Land } & \multirow{2}{*}{$\begin{array}{l}\text { Average } \\
\text { Length of } \\
\text { Stay }\end{array}$} \\
\hline & Number & $\begin{array}{l}\text { Annual } \\
\text { Growth } \\
\text { rate }(\%)\end{array}$ & Number & Percent & Number & percent & \\
\hline 1962 & 6,179 & 0.0 & ---- & ----- & ---- & ---- & ---- \\
\hline 1965 & 9,388 & -1.4 & 8,303 & 88.4 & 1,085 & 11.6 & ---- \\
\hline 1970 & 45,970 & 31.7 & 36,508 & 79.4 & 9,462 & 20.6 & ---- \\
\hline 1975 & 92,440 & 2.9 & 78,995 & 85.5 & 13,445 & 14.5 & 13.05 \\
\hline 1980 & 162,897 & 0.4 & 139,387 & 85.6 & 23,510 & 14.4 & 11.18 \\
\hline 1985 & 180,989 & 2.5 & 151,870 & 83.9 & 29,119 & 16.1 & 11.30 \\
\hline 1990 & 254,884 & 6.2 & 226,421 & 88.8 & 28,464 & 11.2 & 12.00 \\
\hline 1995 & 363,395 & 11.3 & 325,035 & 89.4 & 38,360 & 10.6 & 11.27 \\
\hline 2000 & 463,646 & -5.7 & 376,914 & 81.3 & 86,732 & 18.7 & 11.88 \\
\hline 2005 & 375,398 & -2.6 & 277,346 & 73.9 & 98,052 & 26.1 & 9.09 \\
\hline 2010 & 602,867 & 18.2 & 448,800 & 74.4 & 154,067 & 25.6 & 12.07 \\
\hline 2012 & 803,092 & 9.1 & 598,258 & 74.5 & 204,834 & 25.5 & 12.16 \\
\hline
\end{tabular}

Source: Nepal Tourism Statistics 2012

The available transport service, whether it may be air or land has a crucial factor to attract tourists in the country. More than 80 percent tourists came to Nepal by air transport. In the early years above 80 percent tourists uses air service while visiting Nepal and below 20 percent tourists they came by land transport service. However, the mode of transport of tourists visiting Nepal has changed since 2002. Since 2002, except the year 2003, below 80 percent tourists came by air and above 20 percent came via land. This may be due to the increasing road and transport facilities in the country.

The tourists' length of stay in the country has important role in tourism development. Higher length of stay is more beneficial for the country. In Nepal shortest length of stay of tourists is recorded 7.92 days in 2002 and the longest 13.51 days in the year 2004 during the period 1962 and 2012. The average length of stay of tourists in Nepal is about 11.0 days. The trend shows stagnation around 11 days in the tourist's length of stay in the years 2007, 2008 and 2009. However, in the year 2012 it increased to 12.16 days.

\section{TOURIST ARRIVAL BY PURPOSE OF VISIT}

Tourists visit Nepal with various purposes. Numerous natural and cultural sites of Nepal, its diverse topography, varied climate, its diverse flora and fauna, different shrines and temples, jungle safari, trekking, different heritage attracts in Nepal. Table 2 shows the purposes of visit in Nepal in different period.

According to the data most of the tourists visiting Nepal come for holiday/pleasure purpose. Since the beginning above 75 percent tourists of arriving Nepal came with the holiday/pleasure purpose and it continued till 1990. And the number of tourists coming for trekking/mountaineering purpose has been increasing with the share growing from $0.4 \%$ in 1965 to $13.1 \%$ in 2012. According to the data for 2012, most of tourists came for holiday pleasure followed by religious purposes and trekking and mountaineering. 
Table 2: Tourist arrivals by purpose of visit (1962-2012)

\begin{tabular}{|c|c|c|c|c|c|c|c|c|}
\hline Year & $\begin{array}{l}\text { Holiday } \\
\text { pleasure }\end{array}$ & $\begin{array}{c}\text { Trekking } \\
\text { and } \\
\text { mountaineering }\end{array}$ & Business & pilgrimage & official & $\begin{array}{l}\text { Conv. } \\
\text { Conf. }\end{array}$ & Others & Total \\
\hline 1962 & - & - & - & - & - & - & - & $\begin{array}{l}6,179 \\
(100)\end{array}$ \\
\hline 1965 & $\begin{array}{l}8,815 \\
(93.9)\end{array}$ & $\begin{array}{c}40 \\
(0.4) \\
\end{array}$ & $\begin{array}{l}160 \\
(1.7)\end{array}$ & - & $\begin{array}{l}372 \\
(4.0) \\
\end{array}$ & - & $\begin{array}{c}1 \\
(0.0)\end{array}$ & $\begin{array}{l}9,388 \\
(100)\end{array}$ \\
\hline 1970 & $\begin{array}{c}41,881 \\
(91.1) \\
\end{array}$ & $\begin{array}{l}556 \\
(1.2) \\
\end{array}$ & $\begin{array}{l}918 \\
(2.0) \\
\end{array}$ & - & $\begin{array}{l}1,528 \\
(3.3)\end{array}$ & - & $\begin{array}{l}1,087 \\
(2.4)\end{array}$ & $\begin{array}{c}45,970 \\
(100) \\
\end{array}$ \\
\hline 1975 & $\begin{array}{c}20,124 \\
(75.9) \\
\end{array}$ & $\begin{array}{l}12,587 \\
(13.6) \\
\end{array}$ & $\begin{array}{l}4,911 \\
(5.3) \\
\end{array}$ & - & $\begin{array}{l}4,277 \\
(4.6) \\
\end{array}$ & - & $\begin{array}{l}591 \\
(0.6) \\
\end{array}$ & $\begin{array}{c}92,440 \\
(100) \\
\end{array}$ \\
\hline 1980 & $\begin{array}{c}130,600 \\
(80.2) \\
\end{array}$ & $\begin{array}{c}19,302 \\
(11.8) \\
\end{array}$ & $\begin{array}{l}5,491 \\
(3.4) \\
\end{array}$ & - & $\begin{array}{l}4,654 \\
(2.9)\end{array}$ & - & $\begin{array}{r}2,850 \\
(1.7)\end{array}$ & $\begin{array}{c}162,897 \\
(100)\end{array}$ \\
\hline 1985 & $\begin{array}{c}128,217 \\
(70.8)\end{array}$ & $\begin{array}{l}28,707 \\
(15.9)\end{array}$ & $\begin{array}{c}10,416 \\
(5.8)\end{array}$ & - & $\begin{array}{l}9,230 \\
(5.1)\end{array}$ & - & $\begin{array}{l}4,419 \\
(2.4)\end{array}$ & $\begin{array}{c}180,989 \\
(100)\end{array}$ \\
\hline 1990 & $\begin{array}{c}161,839 \\
(63.5)\end{array}$ & $\begin{array}{l}39,999 \\
(15.70\end{array}$ & $\begin{array}{c}11,728 \\
(4.6)\end{array}$ & $\begin{array}{l}6,713 \\
(2.6)\end{array}$ & $\begin{array}{c}26,578 \\
(10.4)\end{array}$ & $\begin{array}{c}2,838 \\
(1.1)\end{array}$ & $\begin{array}{c}26,578 \\
(10.4)\end{array}$ & $\begin{array}{c}254,885 \\
(100)\end{array}$ \\
\hline 1995 & $\begin{array}{c}183,207 \\
(50.4)\end{array}$ & $\begin{array}{l}84,787 \\
(23.3) \\
\end{array}$ & $\begin{array}{c}21,829 \\
(6.0)\end{array}$ & $\begin{array}{l}5,257 \\
(1.4)\end{array}$ & $\begin{array}{c}20,040 \\
(5.5)\end{array}$ & $\begin{array}{l}5,272 \\
(1.5)\end{array}$ & $\begin{array}{c}42,953 \\
(11.8)\end{array}$ & $\begin{array}{c}363,395 \\
(100)\end{array}$ \\
\hline 2000 & $\begin{array}{c}255,889 \\
(55.2) \\
\end{array}$ & $\begin{array}{c}118,780 \\
(25.6) \\
\end{array}$ & $\begin{array}{c}29,454 \\
(6.4) \\
\end{array}$ & $\begin{array}{c}15,801 \\
(3.4) \\
\end{array}$ & $\begin{array}{c}20,832 \\
(4.5) \\
\end{array}$ & $\begin{array}{c}5,599 \\
(1.2) \\
\end{array}$ & $\begin{array}{c}17,291 \\
(3.7) \\
\end{array}$ & $\begin{array}{c}463,646 \\
(100) \\
\end{array}$ \\
\hline 2005 & $\begin{array}{c}160,259 \\
(42.7)\end{array}$ & $\begin{array}{l}61,488 \\
(41.4) \\
\end{array}$ & $\begin{array}{c}21,992 \\
(5.9)\end{array}$ & $\begin{array}{l}47,621 \\
(12.7)\end{array}$ & $\begin{array}{c}16,859 \\
(4.5)\end{array}$ & - & $\begin{array}{l}67,179 \\
(17.9)\end{array}$ & $\begin{array}{c}375,398 \\
(100)\end{array}$ \\
\hline 2010 & $\begin{array}{c}263,938 \\
(43.8) \\
\end{array}$ & $\begin{array}{c}70,218 \\
(11.6) \\
\end{array}$ & $\begin{array}{c}21,377 \\
(3.5) \\
\end{array}$ & $\begin{array}{c}101,335 \\
(16.8)\end{array}$ & $\begin{array}{c}26,374 \\
(4.4)\end{array}$ & $\begin{array}{l}9,627 \\
(1.6)\end{array}$ & $\begin{array}{c}109,998 \\
(18.24)\end{array}$ & $\begin{array}{c}602,867 \\
(100)\end{array}$ \\
\hline 2012 & $\begin{array}{c}379,627 \\
(47.3)\end{array}$ & $\begin{array}{c}105,015 \\
(13.1)\end{array}$ & $\begin{array}{c}24,785 \\
(3.1)\end{array}$ & $\begin{array}{c}109,854 \\
(13.7)\end{array}$ & $\begin{array}{c}30,460 \\
(3.8)\end{array}$ & $\begin{array}{c}13,646 \\
(1.7)\end{array}$ & $\begin{array}{c}139,705 \\
(17.4)\end{array}$ & $\begin{array}{c}803,092 \\
(100)\end{array}$ \\
\hline
\end{tabular}

Figures in parenthesis represent percentage of the total.

Source: Nepal Tourism Statistics, 2012

\section{TOURISTS ARRIVAL BY SEX AND AGE GROUP}

The sex wise trend of tourist arrivals in Nepal shows that the number of male tourists is larger than that of female tourists. Visitors of Nepal are mainly dominated by the male visitors except the year 2011. In the year 1962 almost half the tourists (47.7) were females, but in the following year it was in a decreasing trend and the ratio reached at the lowest 31.3 percent in 2005. In the year 2012 the ratio of male and female tourists' arrivals were 54.7 and 45.3 respectively of the total arrivals. It indicates that there is a need to develop appropriate situation to attract the female visitors in Nepal 
Table 3: Tourists arrival by sex and age group, 1962-2012

\begin{tabular}{|c|c|c|c|c|c|c|c|c|c|}
\hline \multirow[t]{3}{*}{ Year } & \multicolumn{2}{|r|}{ Sex } & \multirow{3}{*}{$\begin{array}{r}\text { Total } \\
0-15 \text { yrs }\end{array}$} & \multicolumn{6}{|c|}{ Age group } \\
\hline & & & & \multirow[t]{2}{*}{$16-30 \mathrm{yrs}$} & \multirow[t]{2}{*}{$31-45$ yrs } & \multirow[t]{2}{*}{$46-60$ yrs } & \multirow[t]{2}{*}{$61+y r s$} & \multirow{2}{*}{$\begin{array}{l}\text { Not } \\
\text { stated }\end{array}$} & \\
\hline & Male & Female & & & & & & & \\
\hline \multirow[t]{2}{*}{1962} & 3,231 & 2,948 & 6,179 & - & - & - & - & - & - \\
\hline & $(52.3)$ & $(47.7)$ & (100) & & & & & & \\
\hline \multirow[t]{2}{*}{1965} & 5,226 & 4,146 & 9,388 & 150 & 2,563 & 2,375 & 2,272 & 2,028 & - \\
\hline & (55.7) & $(44.3)$ & (100) & (1.6) & (27.3) & (25.3) & $(24.2)$ & (21.6) & \\
\hline \multirow[t]{2}{*}{1970} & 26,157 & 19,813 & 45,970 & 1,613 & 16,302 & 11,240 & 9,559 & 7,256 & - \\
\hline & $(56.9)$ & $(43.1)$ & $(100)$ & $(3.5)$ & $(35.5)$ & $(24.5)$ & $(20.8)$ & $(15.7)$ & \\
\hline \multirow[t]{2}{*}{1975} & 55,741 & 36,699 & 92,440 & 2,958 & 36,514 & 27,177 & 16,824 & 8,976 & - \\
\hline & $(60.3)$ & $(39.7)$ & $(100)$ & (3.2) & (39.5) & $(29.4)$ & (18.2) & (9.7) & \\
\hline \multirow[t]{2}{*}{1980} & 100,061 & 62,891 & 162,897 & 6,914 & 59,724 & 48,786 & 31,544 & 15,929 & - \\
\hline & $(61.4)$ & $(38.6)$ & $(100)$ & $(4.2)$ & $(36.7)$ & (29.9) & (19.4) & (9.8) & \\
\hline \multirow[t]{2}{*}{1985} & 113,862 & 67,426 & 180,985 & 9,497 & 58,861 & 61,528 & 33,520 & 17,583 & - \\
\hline & $(62.8)$ & $(37.2)$ & $(100)$ & (5.2) & $(32.5)$ & $(34.0)$ & (18.6) & (9.7) & \\
\hline \multirow[t]{2}{*}{1990} & 155,311 & 99,574 & 254,885 & 10,620 & 85,903 & 82,292 & 49,388 & 26,682 & - \\
\hline & $(60.9)$ & $(39.1)$ & $(100)$ & $(4.2)$ & $(33.7)$ & $(32.3)$ & (19.4) & $(10.4)$ & \\
\hline \multirow[t]{2}{*}{1995} & 224,769 & 138,626 & 363,395 & 22,878 & 106,603 & 120,212 & 76,647 & 37,055 & - \\
\hline & $(61.9)$ & $(38.1)$ & $(100)$ & $(6.3)$ & $(29.3)$ & $(33.1)$ & $(21.1)$ & $(10.2)$ & \\
\hline \multirow[t]{2}{*}{2000} & 266,937 & 196,709 & 463,646 & 19,136 & 119,816 & 148,063 & 125,140 & 51,491 & - \\
\hline & $(57.6)$ & $(42.4)$ & $(100)$ & $(4.1)$ & $(25.8)$ & (31.9) & $(27.0)$ & (11.1) & \\
\hline \multirow[t]{2}{*}{2005} & 257,972 & 117,426 & 375,398 & 30,429 & 57,115 & 114,103 & 106,077 & 67,674 & - \\
\hline & $(68.7)$ & $(31.3)$ & $(100)$ & $(8.1)$ & $(21.2)$ & $(30.4)$ & $(28.3)$ & $(18.0)$ & \\
\hline \multirow[t]{2}{*}{2010} & 361,611 & 241,256 & 602,867 & 41,156 & 120,395 & 189,852 & 172,800 & 64,593 & 14,071 \\
\hline & $(60.0)$ & $(40.0)$ & $(100)$ & $(6.8)$ & $(20.0)$ & $(31.5)$ & $(28.7)$ & $(10.7)$ & (2.3) \\
\hline \multirow[t]{2}{*}{2012} & 439,270 & 363,822 & 803,092 & 35,468 & 181,558 & 231,117 & 201,835 & 109,239 & 43,875 \\
\hline & $(54.7)$ & $(45.3)$ & (100) & $(4.4)$ & $(22.6)$ & $(28.8)$ & $(25.1)$ & (13.6) & $(5.5)$ \\
\hline
\end{tabular}

Figures in parenthesis represent percentage of the total

Source: Nepal Tourism Statistics, 2012,

According to the age category, in the early periods the highest share was occupied by the younger age group 16-30 followed by the age group of 31-45, 4660 \& over and 0-15 since 1965 to 1990 except in 1985 tourist arrivals trend in Nepal. But since the year 1992 to 2012 the trend showed that the age group of 31-45 has a higher share and age group and followed by 16-30, 46- 60, 61 and 0-15 age group. In the year 2012 among the total tourist arrivals 55.8 percent were under the age of 45 and 38.7 percent were over the age of 45 years and the rest 5.5 percent tourists has not specified the age group.
It shows that Nepal is popular both for youths and adults visitors.

\section{SEASONAL TREND OF TOURIST ARRIVALS}

There are certain periods when the influx of tourists is high. March-April of spring season and OctoberNovember of autumn season are the four months with peak seasons for tourist coming to Nepal. The lowest arrivals are in the month of June and July. However, recently there is indication that tourists are coming to Nepal slowly in other seasons too. 


\begin{tabular}{|c|c|c|c|c|c|c|c|c|c|c|c|c|}
\hline 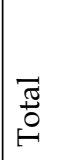 & 今ે & 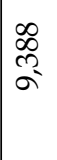 & $\begin{array}{l}2 \\
\text { مa } \\
\text { bे }\end{array}$ & $\begin{array}{l}\text { 亲 } \\
\text { d }\end{array}$ & 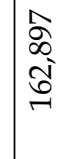 & 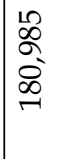 & 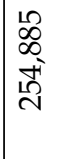 & $\begin{array}{l}0 \\
\alpha \\
\infty \\
\infty \\
\infty \\
\infty\end{array}$ & 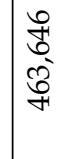 & $\begin{array}{l}\infty \\
\infty \\
0 \\
10 \\
c\end{array}$ & 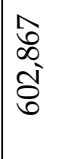 & 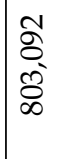 \\
\hline ஹٌ & $\frac{5}{9}$ & 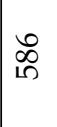 & $\begin{array}{l}\tilde{N} \\
\tilde{n} \\
i n\end{array}$ & 莣 & 总 & बત્તે & 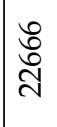 & 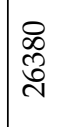 & $\begin{array}{l}\text { 苦 } \\
\text { a }\end{array}$ & 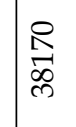 & $\begin{array}{l}\text { 辛 } \\
\text { in }\end{array}$ & 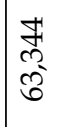 \\
\hline z & \&̊) & $\not$ & $\mid \begin{array}{l}\infty \\
\vdots \\
\vdots\end{array}$ & $\begin{array}{l}\text { d్ర } \\
\text { a }\end{array}$ & $\begin{array}{l}\text { 总 } \\
\stackrel{2}{1}\end{array}$ & $\begin{array}{l}\text { के } \\
\text { ते }\end{array}$ & $\begin{array}{l}\text { 슬 } \\
\text { ल्d }\end{array}$ & $\mid \begin{array}{l}\infty \\
\infty \\
\infty \\
c \\
c\end{array}$ & 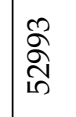 & $\begin{array}{l}180 \\
10 \\
7\end{array}$ & 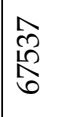 & 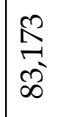 \\
\hline 过 & $\stackrel{\bullet}{\sigma}$ & 苋 & 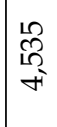 & 鸽 & 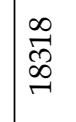 & 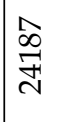 & 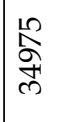 & 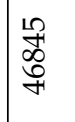 & 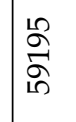 & $\mid \begin{array}{l}\infty \\
\text { ô } \\
\text { in }\end{array}$ & 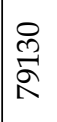 & 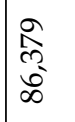 \\
\hline هั & $\begin{array}{l}\infty \\
\text { ల్ }\end{array}$ & 命 & $\mid \begin{array}{l}0 \\
0 \\
0\end{array}$ & 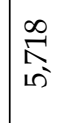 & 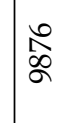 & $\begin{array}{l}\text { 足 } \\
\text { J }\end{array}$ & $\begin{array}{l}\vec{d} \\
\infty \\
\text { ते }\end{array}$ & $\begin{array}{l}\text { oे } \\
\text { o. } \\
\text { n. }\end{array}$ & 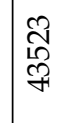 & $\begin{array}{l}0 \\
\text { o: } \\
\infty\end{array}$ & 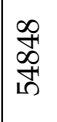 & 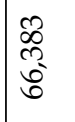 \\
\hline$\frac{100}{2}$ & 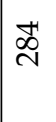 & $\infty$ & $\begin{array}{l}7 \\
0 \\
10^{2}\end{array}$ & $\begin{array}{l}\vec{D} \\
W^{\circ} \\
\infty^{2}\end{array}$ & 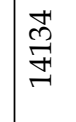 & 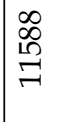 & 空 & 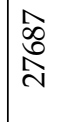 & 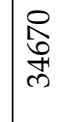 & 竎 & 芯 & 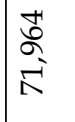 \\
\hline$\dot{\Xi}$ & \& & 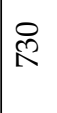 & $\begin{array}{l}\stackrel{8}{\circ} \\
\stackrel{f}{+}\end{array}$ & 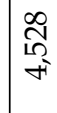 & 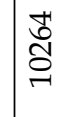 & 芯 & 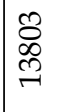 & $\begin{array}{l}\mathscr{D} \\
\text { ồ }\end{array}$ & 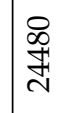 & $\begin{array}{l}\text { ڤొ } \\
\text { స్ }\end{array}$ & 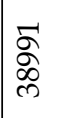 & 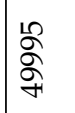 \\
\hline$\underline{\Xi}$ & $\widehat{\widehat{~}}$ & 首 & 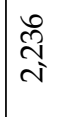 & $\underset{F}{F}$ & 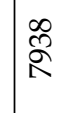 & Sू & $\begin{array}{l}\vec{\partial} \\
\vec{\sigma} \\
\vec{F}\end{array}$ & $\begin{array}{l}\stackrel{\circ}{0} \\
\text { uñ }\end{array}$ & 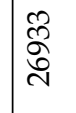 & $\mid$\begin{tabular}{l}
$\infty$ \\
\multirow{a}{0}{} \\
|
\end{tabular} & $\begin{array}{l}\text { तु } \\
\text { ल) }\end{array}$ & 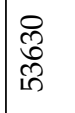 \\
\hline छ্ & 市 & $\stackrel{0}{1}$ & 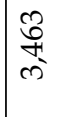 & $\begin{array}{l}7 \\
\infty^{\circ}\end{array}$ & 总 & 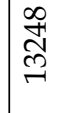 & 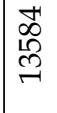 & 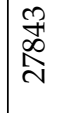 & 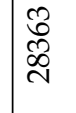 & 壱 & 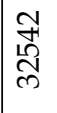 & $\begin{array}{l}\text { ले } \\
\text { 总 }\end{array}$ \\
\hline 安 & సે & 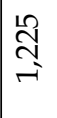 & $\mid \begin{array}{l}8 \\
0 \\
0^{\circ}\end{array}$ & 总 & $\mid$\begin{tabular}{l}
$\infty$ \\
0 \\
0 \\
\hdashline \\
\hdashline
\end{tabular} & 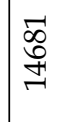 & 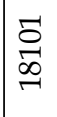 & 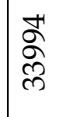 & 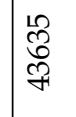 & 䒿 & $\begin{array}{l}\text { 㔛 } \\
\text { 学 }\end{array}$ & 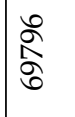 \\
\hline 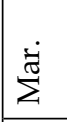 & 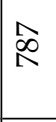 & $\vec{m}$ & 食 & $\stackrel{\stackrel{p}{7}}{\vec{F}}$ & $\mid \begin{array}{l}\mathbb{8} \\
\mathbb{1} \\
\end{array}$ & 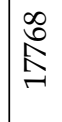 & 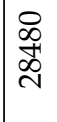 & 今ે & 委 & $\mid \begin{array}{l}10 \\
\text { od } \\
\text { No }\end{array}$ & 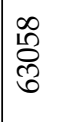 & 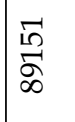 \\
\hline 这 & ஜे & 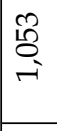 & 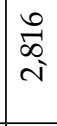 & $\underset{f}{\stackrel{J}{7}}$ & $\begin{array}{l}\vec{y} \\
\vec{f}\end{array}$ & 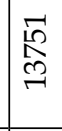 & $\mid \begin{array}{l}\infty \\
\infty \\
\infty \\
\sim \\
\sim\end{array}$ & $\begin{array}{l}\mathcal{P} \\
\text { od } \\
\text { d }\end{array}$ & 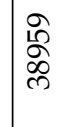 & $\begin{array}{l}\infty \\
\infty \\
\tilde{\tilde{C}} \\
\end{array}$ & 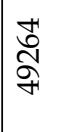 & 产 \\
\hline 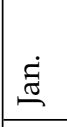 & \&্ঠे & $\begin{array}{l}\infty \\
0 \\
1\end{array}$ & 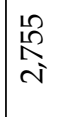 & $\begin{array}{l}0 \\
0 \\
0 \\
\vdots \\
0\end{array}$ & 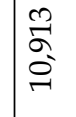 & 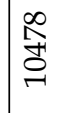 & $\begin{array}{l}\text { नि } \\
\text { హे }\end{array}$ & $\begin{array}{l}\hat{a} \\
\tilde{y}\end{array}$ & 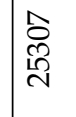 & 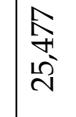 & 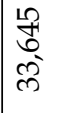 & 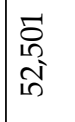 \\
\hline ְँ & ळু & $\begin{array}{l}2 \\
2 \\
2\end{array}$ & & 点 & $\begin{array}{l}\mathscr{8} \\
9\end{array}$ & 足 & 2 & $\begin{array}{l}\text { L } \\
2\end{array}$ & ర্ণী & 赵 & त्̀̆ & तै \\
\hline
\end{tabular}




\section{CONCLUSION}

Present paper was prepared with an objective to analyze the trend of tourist arrivals in Nepal. Tourism arises from a movement of people to the destination. It involves two basic activities: the journey to the destination and activities at the destination. Travelling is a human character since the beginning of human civilization but tourism is a phenomenon of modern times. It is the most important source of income for many regions. Different type of flora and fauna, national parks, lakes, rivers, waterfalls, mountains, caves, gorge, spas, hot springs etc. are the natural attractions in Nepal. The major cultural attractions are historical sites and buildings, archeological sites, zoo and museum, different type of events, sports, trade fair exhibitions, religious place, entertainment, festival, ceremonies etc in Nepal. As mentioned earlier, tourism in Nepal started since 1950. The trend of tourists visiting Nepal seems satisfactory. Tourism industry has emerged as a sector that contributes a lot to the country by creating jobs and by reaching development to remote and far off areas that has turned out a corner stone in alleviating poverty. Thus, to promote tourism sector and its contribution to socio-economic sector of the country, we need to utilize available resources properly and beneficially. For this, there is a need of dynamic and tourism friendly policy and joint effort of the government and the private sector for the development of tourism in Nepal.

\section{REFERENCES}

Bhandari, D. R.1973. Nepalko Yetihasik Bibechana, Varanasi: Krishna Kumari Devi.

Gautam, R.1995. Yetihashik Sugauli Sandhi Kasari Lagoo Bhayo?, Gorkhapatra, 2052/2/1, Kathmandu.

Ghimire, A. 2004. Travel and tourism an introduction, Kathmandu: Ekta Books.

Gurung, H. 1978. 'Tourism Trends in Nepal', Industrial Digest, Kathmandu: Nepal Industrial Development Corporation, vol.8, No. 1.

http:// www. Scribd.com/doc. Retrieved on February 15, 2014.)

MoCTCA, 2013. Nepal Tourism Statistics 2012. Kathmandu: Ministry of culture, tourism and civil aviation. (http://www. Tourism. Gov.np. retrieved on 15 february 2014).

Ranjit, S. R.1976. Tourist Industry with Special Reference to Foreign Exchange Earnings and Resort Development (Unpublished Master's Dissertation) submitted to IBACPA, Tribhuvan University, Kathmandu.

Satyal, Y. R. 1988. Tourism in Nepal A Proile, Varanasi, India, Nath Publishing House.

Shrestha, H. P. 1978. A Study on Factors Affecting the Tourist Influx in Nepal with Special Reference to Accommodation,Transportation and Publicity (Unpublished Master's Dissertation submitted to IBACPA), Tribhuvan University, Kathmandu.

Shrestha, H. P. and Shrestha, P. 2012. Tourism in Nepal: A Historical perspectives and Present Trend of development, Himalayan Journal of Sociology and Anthropology. Retrieved on February 15, 2014. 